\title{
Inclusion levels of flour made from smoked Nile tilapia trimmings in extruded corn
}

\section{snacks}

\author{
Níveis de inclusão de farinha feita com aparas de tilápia do Nilo defumada em snacks extrusados de \\ milho
}

Niveles de inclusión de harina hecha de recortes de tilápia del Nilo ahumados em bocadillos de maíz extruido

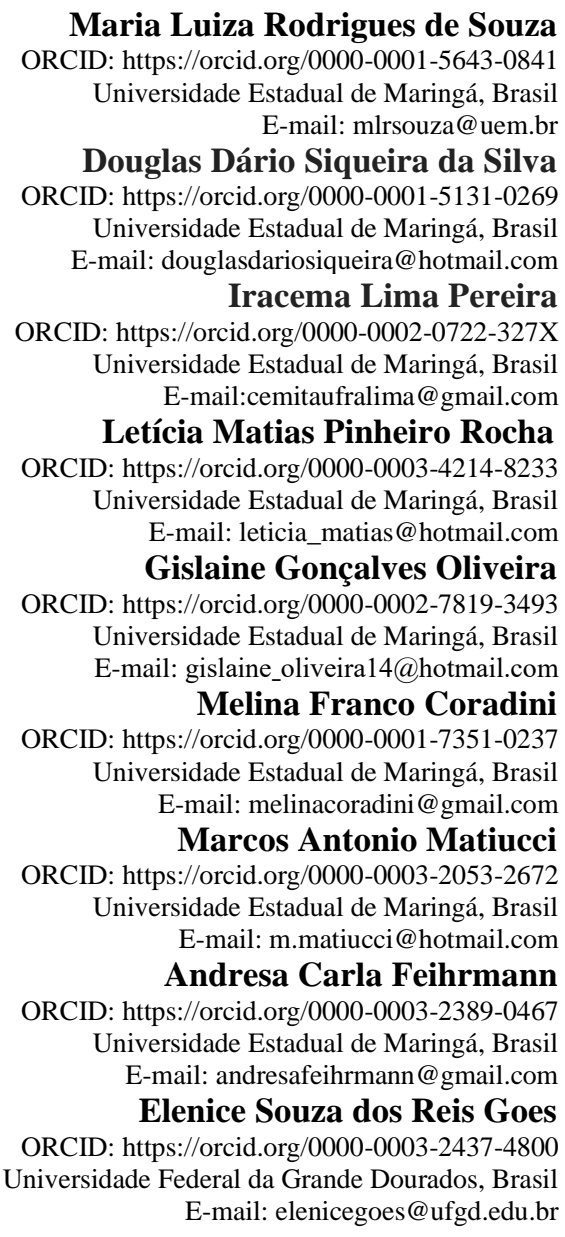

\begin{abstract}
This study aimed to elaborate extruded corn snacks with the inclusion of flour made from smoked Nile tilapia trimmings, as well as evaluate the chemical, sensory and microbiological composition. The tilapia trimmings flour was incorporated in four levels, one of them was the control (without inclusion) and then 5\%, 10\% and 15\% added in the corn grits. The microbiological analysis shows that the flours and snacks prepared are within the microbiological standards. The shavings flour presented $8.89 \%$ moisture, $60.87 \%$ protein, $15.7 \%$ ash and $11.68 \%$ carbohydrates. The inclusion of different levels of tilapia flour in the extruded snacks significantly influenced only the content of protein, moisture and carbohydrates. The protein content increased as the level of inclusion of shavings in the snacks increased, while the carbohydrate content decreased. For protein, there was a positive linear effect, whose contents went from $7.06 \%$ to $11.44 \%$. Carbohydrate had a negative linear effect, reducing from $78.20 \%$ to $72.63 \%$. The moisture content showed a quadratic effect, with a range from 5.26 to $6.03 \%$. As for sensory analysis, there was no significant difference for any of the attributes evaluated between the different treatments. It is recommended to include up to $15 \%$ of Nile tilapia
\end{abstract}


trimmings flour in extruded corn snacks with an increase in protein content of up to $38.29 \%$ and a reduction of up to $7.12 \%$ in carbohydrates.

Keywords: V-type fillet cut; Oreochromis niloticus; Fillet by-product.

\section{Resumo}

Este trabalho teve como objetivo elaborar snacks extrusados de milho com a inclusão de farinha de aparas defumadas de tilápia do Nilo, bem como avaliar a composição química, microbiológica e sensorial. A farinha das aparas de tilápia foi incorporada em quatro níveis, sendo um deles o controle (sem inclusão) e a seguir 5\%, 10\% e $15 \%$ adicionados nos grãos de milho. As análises microbiológicas mostraram que as farinhas e snacks preparados estavam dentro dos padrões microbiológicos. A farinha de aparas apresentou 8,89\% de umidade, 60,87\% de proteína, 15,7\% de cinzas e 11,68\% de carboidratos. A inclusão de diferentes níveis de farinha de tilápia nos snacks extrusados influenciou significativamente apenas no teor de proteína, umidade e carboidratos. O teor de proteína aumentou com o aumento do nível de inclusão de farinhas nos snacks, enquanto o teor de carboidratos diminuiu. Para a proteína, houve efeito linear positivo, cujos teores passaram de 7,06\% para 11,44\%. Os carboidratos tiveram um efeito linear negativo, reduzindo de 78,20\% para 72,63\%. O teor de umidade apresentou efeito quadrático, com variação de 5,26 a 6,03\%. Quanto à análise sensorial, não houve diferença significativa para nenhum dos atributos avaliados entre os diferentes tratamentos. Recomenda-se incluir até $15 \%$ da farinha de aparas de tilápia do Nilo nos snacks extrusados de milho, com aumento no teor de proteína de até $38,29 \%$ e redução de até $7,12 \%$ nos carboidratos.

Palavras-chave: Corte em V do filé; Oreochromis niloticus; Subproduto do filé.

\section{Resumen}

Este estudio tuvo como objetivo elaborar botanas de maíz extruido con la inclusión de harina de recortes de tilapia del Nilo ahumada, así como evaluar la composición química, microbiológica y sensorial. La harina de recortes de tilapia se incorporó en cuatro niveles, uno de ellos fue el control (sin inclusión) y luego se agregó 5\%, 10\% y 15\% en la sémola de maíz. Los análisis microbiológicos mostraron que las harinas y snacks preparados se encuentran dentro de los estándares microbiológicos. La harina de virutas presentó $8.89 \%$ de humedad, $60.87 \%$ de proteína, $15.7 \%$ de ceniza y $11.68 \%$ de carbohidratos. La inclusión de diferentes niveles de harina de tilapia en los bocadillos extruidos influyó significativamente solo en el contenido de proteína, humedad y carbohidratos. El contenido de proteína aumentó a medida que aumentó el nivel de inclusión de virutas en los bocadillos, mientras que el contenido de carbohidratos disminuyó. Para la proteína, hubo un efecto lineal positivo, cuyo contenido pasó de 7.06\% a 11.44\%. Los carbohidratos tuvieron un efecto lineal negativo, reduciéndose del 78,20\% al 72,63\%. El contenido de humedad mostró un efecto cuadrático, con un rango de 5,26 a 6,03\%. En cuanto al análisis sensorial, no hubo diferencia significativa para ninguno de los atributos evaluados entre los diferentes tratamientos. Se recomienda incluir hasta un $15 \%$ de harina de recortes de tilapia del Nilo en snacks de maíz extruido con un aumento en el contenido de proteínas de hasta $38.29 \%$ y una reducción de hasta $7.12 \%$ en carbohidratos.

Palabras clave: Filete cortado tipo V; Oreochromis niloticus; Subproducto fileteado.

\section{Introduction}

Production of tilapia fillet is growing as a way of aggregating aquaculture production, on the other hand, the levels of waste have also been growing and there is the need to have a correct destination, avoiding environmental impact (Ariño et al., 2013; Matiucci et al., 2021). Some authors reported fillet residue values of $50 \%$ of the raw material ranging from $60 \%$ to $72 \%$ (Pires et al., 2014; Boscolo, et al., 2007; Kubtiza, 2006), at 65\% of the slaughter weight depending on different factors. Among them the species, slaughter method, function of the final product or species of fish. The tilapia residues generated in the filleting industries are around $54 \%$ for head, viscera, carcass, $10 \%$ skin, $1 \%$ scales and $5 \%$ dorsal and ventral trimmings from v-cuts (Vidotti, 2006).

Therefore, fillet by-products need technological applications for the development of commercial products or raw materials for secondary processes, as a way to add value to the production chain and greater sustainability to the sector. This use is extremely important, decreasing costs, increasing production efficiency, reducing environmental problems that they would no longer have for simply giving this waste an adequate destination.

Fish have high nutritional content, provide high quality proteins, are rich in omega 3 and 6 essential amino acids, being a good source of vitamins and minerals (Ariño et al., 2013). In order to increase fish consumption and reduce waste, one of the best alternatives is to boost the supply and diversification of fish products as convenient foods, ready for consumption and that 
facilitate the handling of this product (Pires et al., 2014). Tilapia is one of the most widely used fish species for filleting, in addition to being considered of great importance in Brazilian aquaculture, especially in Paraná, it is also recommended for intensive cultivation in net tanks, excavated tanks and shallow tanks (Goes et al., 2015). It is widely accepted by the consumer market, it has technology compatible with zootechnical production and is the most appropriate for the filleting industry due to the absence of spines in its fillet (Ariño et al., 2013). This is because there is only a series of fishbones that are removed in the filleting process, by cutting the fillet in a "V" shape, which is even considered as filleting trimmings.

It is evident that, in order to be suitable for human consumption, these residues must be classified and then have an appropriate destination in terms of keeping the temperature low, and appropriate storage in order to avoid any development of microorganisms and not interfere with nutritional quality. Among these residues, there is one in particular, the "V" cut of the fillet or shavings, which, when the industry has a pulping machine, is also included with the carcasses in the production of mechanically separated meat (MSM). However, another alternative that has shown good results is frozen grinding to break the fishbones, in the preparation of products (Souza et al., 2017) or the flour to be included in food products.

Usually, when it comes to fish meal, it is known that its mains use is in animal feeding, but currently, due to its high biological value of 70\% (Arruda et al., 2006) or more, it has been studied for human consumption (Souza et al., 2017), through its inclusion in several food products, such as pasta (Goes et al., 2016), lasagna (Kimura et al., 2017), and bread rolls (Chambo et al., 2018).

Fish meal can also be included in extruded corn snacks which, despite being widely consumed by children, contain only crushed corn, oil as a fixative agent for seasonings and salt (sodium chloride) (Capriles et al., 2009). However, this food can be enriched, mainly in protein, and have an appeal to nutritionally improve the product (Ferreira, 2006), with the animal meal (fish).

There is research on the inclusion of flavored flour made from tilapia carcass in snacks (Justen et al., 2011), as well as fillet residues (carcasses) from other fish species such as salmon, tuna and sardines, compared to tilapia (Goes, et al., 2015). Justen et al. (2017) even included up to $12 \%$ of flours made from smoked carcasses and Goes et al. (2015) $9 \%$ of fish meal of different species. However, there are other types of waste, such as the trimmings, that could be included, providing improvements in nutritional and sensory characteristics. In addition, due to the greater amount of meat present in this type of waste and the fact that the trimmings are smoked, the inclusion would interfere in the flavor of the extruded snacks.

Based on this information, this study aims to prepare extruded snacks with levels of inclusion of Nile tilapia trimmings and to evaluate the chemical, sensory and microbiological composition.

\section{Material and Methods}

\subsection{Production of flour made from smoked Nile tilapia trimmings}

This research is characterized as experimental (Pereira et al., 2018). The trimmings or V-type fillet cut were removed from Nile tilapia fillets (Oreochromis niloticus) provided by SmartFish Company in Rolândia (Paraná). The trimmings came from the processing unit frozen, and at the time of the process they were thawed in a refrigerator and washed. The trimmings $(5 \mathrm{~kg})$ were divided into five batches and prepared separately, and then each batch was immersed in 20\% brine (2: 1 - brine volume/weight) for 30 minutes, aromatic herbs extract was also included (rosemary) in the proportion of (1:25) (herbs:water). After, trimmings were drained for 1 hour and subjected to partial drying (in a dehydrator with forced ventilation) at a temperature of $50^{\circ} \mathrm{C}$, for 60 minutes. Then they were placed in the stainless-steel smoker chamber, in which the smoke was added for 3 hours (60 to $80^{\circ} \mathrm{C}$ ). Afterwards, the smoked trimmings were pressed (hydraulic press with a capacity of 10 tons), ground and the mass obtained from the grinding process was placed in a dehydrator with forced ventilation at $60^{\circ} \mathrm{C}$ for 24 hours, then it was crushed and subjected to a new grinding process in a knife mill to obtain a flour of small granulometry $(0.60 \mathrm{~mm})$. This smoked flour was vacuum packed to be included in the extruded snacks. 


\subsection{Production of the extruded snacks}

An Inbramaq extruder (Model IB-50, manufactured in 2009, nominal capacity of $50 \mathrm{~kg} / \mathrm{h}$ ) was used in the production of the extruded snacks.

The smoked tilapia trimmings flour was included in four levels (Treat $1=0 \%$; Treat $2=5 \%$; Treat $3=10 \%$; Treat $4=$ $15 \%)$, one being the control treatment (without the inclusion Treat $1=0 \%)$. The mixture of corn grits $(1 \mathrm{~kg})$ and the different percentages of inclusion of smoked trimmings flour (Treat $1=0 \mathrm{~g}$, Treat $2=50 \mathrm{~g}$; Treat $3=100 \mathrm{~g}$; Treat $4=150 \mathrm{~g}$ ), was homogenized in a container with $20 \mathrm{ml}$ of water added to each treatment.

After being well homogenized, the mixtures mixtures were added directly to the extrusion system inlet using a small sample dispenser. Thus, it was possible to work with mixture samples around $1000 \mathrm{~g}$. Initially, the following process parameters were used for the extrusion: Die Plate: two holes with central cut, main engine chain: 15 to $22 \mathrm{~A}$, cutting knife inverter: five A and homogenizer rotameter: $20 \mathrm{ml} / \mathrm{min}$, and extrusion temperature of $110^{\circ} \mathrm{C}$ (Monteiro, 2011).

After preparing the extruded snacks, samples were separated for analysis of chemical composition, $\mathrm{pH}$, water activity, sensory and microbiological analysis.

\subsection{Microbiological analysis}

The microbiology of smoked Nile tilapia trimmings flour and prepared snacks was carried out at the Food Microbiology and Microscopy laboratory, of the Department of Clinical Analysis at the State University of Maringá (UEM).

Thus, $100 \mathrm{~g}$ samples of each treatment and of the flour were kept in a refrigerator to carry out the determination analysis for the most probable number (MPN) of coliforms at $35^{\circ} \mathrm{C}$ and $40^{\circ} \mathrm{C}$, positive coagulase Staphylococcus count in a forming unit colony (CFU) / gram and Salmonella spp in 25g of sample, according to APHA (2001). The microbiological protocol followed the standards recommended by Resolution RDC $n^{\circ}$ 12, of January 2, 2001, of the National Health Regulatory Agency (Brasil, 2001). Microbiological analyses were carried out only to determine whether the products were fit for human consumption, not for statistical analysis.

\subsection{Physicochemical analysis of flour and extruded snacks}

To assess the proximate composition of flour and snacks, analyses of moisture, crude protein, lipids and ashes were performed. The determinations were made in triplicate from 100g samples. The crude protein content was obtained by the Kjeldahl semi-micro process, in three distinct stages (digestion, distillation and titration), according to Silva \& Queiroz (2002). Moisture and ash were carried out according to the AOAC methodology (2005). The total lipid content was determined using the Bligh \& Dyer (1959) methodology. The determination of the carbohydrate fraction of the samples was carried out by difference, as shown in the equation: $\mathrm{CHO}=100-(\mathrm{MO}+\mathrm{MM}+\mathrm{CP}+\mathrm{EE})$, in which: $\mathrm{CHO}=$ Carbohydrates; $\mathrm{MO}=$ Moisture; $\mathrm{MM}=$ Mineral matter $\mathrm{CP}=$ Crude protein and $\mathrm{EE}=$ Ethereal extract.

The total caloric value was obtained by adding the multiplication of the values of the averages of protein, lipids and carbohydrates multiplied by factors 4, 9 and 4, respectively (Souci et al., 2000).

In order to obtain the $\mathrm{pH}$ of the samples, they were homogenized with distilled water and subjected to reading on the pH meter (DM 22, Digimed). The determination of water activity was performed using the Labswift-Novasina device.

\subsection{Sensory analysis}

Sensory analysis was performed with 100 untrained tasters, who were provided with around $5 \mathrm{~g}$ of samples from each treatment, identified with three random numbers. Along with the identified samples from each treatment, tasters were provided 
with a form to carry out the sensory analysis and a glass of water to remove the residual flavor from the snacks of each treatment between the evaluations performed.

The tasters evaluated the extruded snacks for the sensory aspects of color, aroma, flavor, texture and general impression, based on a structured 9-point hedonic scale, anchored between minimum and maximum: 1 (I disliked it extremely) and 9 (I liked it extremely) (Dutcosky, 2011). The samples were also subjected to the purchase intention test, with a 5-point hedonic scale with extremes 1 (definitely would not buy) and 5 (definitely would buy) (Damasio \& Silva, 1996).

The Acceptability Index (IA) was calculated using the formula: IA $(\%)=(\mathrm{A} / \mathrm{B}) \mathrm{x} 100$, in which $\mathrm{A}=$ represents the average score obtained by the product analyzed on the hedonic scale; $\mathrm{B}=$ represents the maximum grade that the product received on the hedonic scale. To be considered as well accepted by the taster, the result must be $\geq 70 \%$ (Dutcosky, 2011).

University staff and students were asked to be tasters through advertising on the university's premises. The first 100 people who declared they had no health problems related to fish consumption were enrolled. The methods of sensory analysis were approved by the Standing Committee on Ethics in Research with Human Beings (COPEP) of the State University of Maringá, Maringá PR Brazil (CAAE 0361-09).

\subsection{Experimental design and statistical analysis}

The study was carried out in a completely randomized design and the data obtained in the different analyses were submitted to analysis of variance (ANOVA) at $5 \%$ probability significance. To evaluate the effects of the inclusion levels of Nile tilapia shavings in extruded snacks, the SAS Inst computer system was used. Inc., Cary, NC, USA (2010). The inclusion levels were evaluated in comparison to the control (0\%), using Dunnet tests at 5\%, and the behavior of the levels was also assessed, using regression analysis.

\section{Results and Discussion}

\subsection{Microbiological analysis of the flour and extruded snacks}

The microbiological analysis of the Nile tilapia trimmings flour and the snacks (Table 1) followed the standards established by the National Health Regulatory Agency (ANVISA), which requires MPN/g $<3$ for coliforms at $35^{\circ} \mathrm{C}$ and $45^{\circ} \mathrm{C}$, absence of Salmonella ssp and counts inferior than $1 \times 10^{2}$ for coagulase positive Staphylococcus (Brasil, 2001).

The results obtained in the microbiological analyses are in accordance with RDC $\mathrm{n}^{\circ} 12$ (Brasil, 2001), with the absence or low index of investigated microorganisms, indicating good quality of the elaborated raw material and adequate (manufacturing) handling process during the preparation of the extruded corn snacks, which was appropriate (manufacturing) (Table 1).

Table 1. Microbiological analysis of smoked Nile tilapia trimmings flour and extruded snackswith the inclusion of different levels of the flour.

\begin{tabular}{|c|c|c|c|c|}
\hline Products & $\begin{array}{c}\text { Coliforms at } 35^{\circ} \mathrm{C} \\
(\mathrm{MPN} / \mathrm{g})\end{array}$ & $\begin{array}{c}\text { Coliforms at } 45^{\circ} \mathrm{C} \\
(\mathrm{MPN} / \mathrm{g})\end{array}$ & $\begin{array}{c}\text { Coagulase-positive Staphylococcus } \\
(\mathrm{CFU} / \mathrm{g})\end{array}$ & $\begin{array}{c}\text { Salmonella ssp. } \\
25 \mathrm{~g} \\
\end{array}$ \\
\hline $\begin{array}{l}\text { Smoked trimmings } \\
\text { flour }\end{array}$ & $<3$ & $<3$ & $<1 \times 10^{2}$ & ABSENT \\
\hline \multicolumn{5}{|c|}{ Snacks with different levels of flour } \\
\hline $0 \%$ & $<3$ & $<3$ & $<1 \times 10^{2}$ & ABSENT \\
\hline $5 \%$ & $<3$ & $<3$ & $<1 \times 10^{2}$ & ABSENT \\
\hline $10 \%$ & $<3$ & $<3$ & $<1 \times 10^{2}$ & ABSENT \\
\hline $15 \%$ & $<3$ & $<3$ & $<1 \times 10^{2}$ & ABSENT \\
\hline
\end{tabular}


The Nile tilapia trimmings flour and the snacks with added flour obtained good hygiene and health scores following the requirements of ANVISA (Brasil, 2001), and, therefore, are suitable for human consumption.

The microbiological results associated with low moisture levels of the flour and snacks are important to provide the products a better shelf life. According to Coradini et al. (2015), there is a need for conditioning in suitable packaging, impervious to moisture, gases and light to increase shelf life.

\subsection{Physicochemical analysis of flour and extruded snacks}

The flour made from the smoked tilapia trimmings in this study presented contents of $8.89 \%$ moisture, $60.87 \%$ protein, $11.68 \%$ lipids and $15.97 \%$ ash (Table 2). The chemical composition of this trimmings flour was very different from the flours found in the literature, made from tilapia fillet residues. Franco et al. (2013) prepared fish meal by cooking tilapia carcasses (spine without head) and it presented $2.15 \%$ moisture, $45.32 \%$ crude protein, $6.93 \%$ ether extract and $38.03 \%$ ashes. The fish meal from the tilapia spine developed by Petenuci et al. (2010), in turn, showed $14.2 \%$ moisture, $40.8 \%$ crude protein, $18.3 \%$ ash and $25.3 \%$ total lipids. Coradini et al. (2015) used smoking or aromatization in the spine (carcass) without head, that is, a methodology similar to the one used in the fillet trimmings in this experiment. The authors obtained a flour with $4.94 \%$ moisture, $45.84 \%$ protein, $18.31 \%$ lipids and $32.23 \%$ ash. Regardless of the flour obtained by the different researchers, these are considered products with high levels of protein and minerals.

By comparing the results obtained by the trimmings flour in this experiment with the results found in the literature for fish meal in which other types of raw material or methodology were used, it is noted that the protein content of the smoked trimmings flour was much higher than that of cooked carcass flour, reaching $25.55 \%$ to $32.97 \%$ more protein when compared to the levels reported by Petenuci et al. (2010) and Franco et al. (2013), respectively. Depending on the methodology or type of raw material used in the flour production, a reduction of $58.01 \%$ of ash can be obtained, as is the case of the trimmings flour when compared to the content of the tilapia carcass flour (38.03\% ash) reported by Franco et al. (2013).

According to Coradini et al. (2015), the different methodologies for preparing fish meal influence the chemical composition. According to Franco et al. (2013), the levels of crude protein, lipids and ashes in fish meal vary according to the origin of the raw material, which is due to the type of feed provided to the fish and the filleting method employed (amount of meat remaining in the raw material). The method used by Franco et al. (2013) included cooking and pressing the carcasses, with an even greater decrease in moisture and fat rates, Petenuci et al. (2010), in turn, did not press the spines, which resulted in a percentage of moisture and lipids much higher than those reported by Franco et al. (2013). The pressing in the preparation of the flour caused a reduction of $84.86 \%$ of humidity and $72.61 \%$ of lipids, comparing to the mentioned methodologies. Therefore, when comparing the trimmings flour from this experiment with the results reported by Petenuci et al. (2010), who did not press the flour, there was a reduction of $37.39 \%$ in the moisture content and $36.17 \%$ in lipids with the pressing of the smoked trimmings. This shows that the process of preparation of the flour also affects the content of these nutrients, that is, when smoking is used in the preparation process, the loss of moisture and lipids associated with the pressing greatly influences the content of these nutrients.

In addition to the methodology used, Chambo and Souza (2018) also state that the choice of raw material to be used in the production of fish meal has a direct effect on its nutritional composition. The authors compare the flours made with tilapia head, carcass or MSM (mechanically separated meat). They reported that MSM flours have higher levels of protein and lipids, while the tilapia head flour and tilapia carcass flour have the lowest levels. The same authors also mention that the ash contents are higher in head and carcass flours, precisely because the MSM flour is composed of meat residues (skeletal muscle) and only a few bone and cartilage remnants that pass through the pulping machine. Chambo and Souza (2018) also reported that carcass flour has muscle and bones, decreasing the protein (28\%) and fat content (45\%), and increasing the mineral content by $15 \%$, 
compared to MSM. Head flour, on the other hand, has a higher proportion of bones than musculature, consequently the protein (35\%) and lipid (65\%) content is lower, compared to MSM flour.

Therefore, the methodologies, type of residues used to prepare the flours and even the species of fish influence the composition of the flours, and when included in the product, these factors also tended to interfere with the product's chemical composition.

In short, the trimmings flour had a higher protein content and less ash content, compared to those reported by the different authors mentioned above. As for the contents of lipids and moisture, these are reduced with changes in the process of preparing the flours, applying the cooking of the raw material and its pressing after cooking.

The inclusion of the trimmings flour in the extruded snacks caused significant differences in the chemical composition of the snacks. However, the difference was significant only for the levels of protein, moisture and carbohydrates (Table 2). The average levels of lipids, ashes and the caloric value were $6.21 \%, 3.12 \%$ and $35.84 \mathrm{kcal} / 100 \mathrm{~g}$, respectively. These results corroborate in part with those reported by Goes et al. (2015), who elaborated extruded snacks enriched with flours of different fish species (tilapia, salmon, tuna and sardines). The authors reported that the moisture, lipid and carbohydrate contents did not show statistical differences ( $p>0.05$ ) when comparing the inclusion of flour of different species with the control (without fish meal). They also mentioned that the protein content and the mineral matter differed from the control, with the exception of the mineral matter of the tilapia snacks.

Table 2. Chemical composition of Nile tilapia smoked trimmings flour and extruded corn snacks prepared with this flour.

\begin{tabular}{|c|c|c|c|c|c|c|c|}
\hline \multirow{2}{*}{$\begin{array}{c}\text { Chemical } \\
\text { compositio } \\
\text { n }(\%)\end{array}$} & \multirow{2}{*}{$\begin{array}{c}\text { Trimming } \\
\text { s } \\
\text { flour }\end{array}$} & \multicolumn{4}{|c|}{$\begin{array}{l}\text { Levels of inclusion of smoked trimmings flour in } \\
\text { the extruded snacks }(\%)\end{array}$} & \multirow[t]{2}{*}{$\begin{array}{c}\text { P. value } \\
\text {. }\end{array}$} & \multirow[t]{2}{*}{$\begin{array}{c}\mathrm{CV} *(\% \\
\quad)\end{array}$} \\
\hline & & $\mathbf{0}$ & 5 & 10 & 15 & & \\
\hline Moisture & $\begin{array}{c}8,8 \\
9\end{array}$ & $6,03 \pm 0,35$ & $5,47 \pm 0,21$ & $5,26 \pm 0,42$ & $5,94 \pm 0,82$ & 0,0000 & 0,55 \\
\hline Protein & $\begin{array}{l}60 \\
87\end{array}$ & $7,06 \pm 2,57$ & $8,97 \pm 0,66$ & $11,04 \pm 1,41$ & $11,44 \pm 1,81$ & 0,0001 & 2,16 \\
\hline Lipids & 11,68 & $6,39 \pm 0,18$ & $6,07 \pm 0,14$ & $5,88 \pm 0,33$ & $6,50 \pm 0,29$ & 0,2508 & 4,57 \\
\hline Ashes & 15,97 & $2,31 \pm 0,81$ & $3,27 \pm 0,15$ & $3,42 \pm 0,30$ & $3,47 \pm 0,35$ & 0,2701 & 17,98 \\
\hline Carbohydrates & 2,59 & $78,20 \pm 2,84$ & $76,20 \pm 0,84$ & $74,38 \pm 0,98$ & $72,63 \pm 2,73$ & 0,0023 & 0,75 \\
\hline $\mathrm{VC}^{*}$ & 358,96 & $398,61 \pm 2,7$ & $395,31 \pm 0,5$ & $394,62 \pm 1,2$ & $394,81 \pm 1,0$ & 0,4867 & 0,68 \\
\hline (Kcal/100g) & & 7 & 3 & 2 & 3 & & \\
\hline
\end{tabular}

* VC - Caloric value in Kcal / 100g. ** Means \pm standard deviation. CV = Coefficient of Variation. Source: Authors

Control snacks according to Goes et al. (2015) presented 6.82\% protein, and when including fish carcass flour there was an increase in protein values, for tuna the content was $11.85 \%$ and for tilapia $9.80 \%$, indicating an increase in the protein content of snacks with the inclusion of these flours. These authors included $9 \%$ of fishmeal in the snacks. In snacks also including 9\% flour of tilapia carcasses, in this case smoked, Justen et al. (2017) reported that the extruded snacks had 10.28\% protein and $3.97 \%$ mineral matter. However, these protein levels reported by the authors have increased when compared to the control (without flour), and these authors have already analysed snacks with fish meal, regardless of the fish species, type of flour processing (with or without smoking, simple cooking method), or origin (carcass or trimmings). Thus, the results show an enrichment of proteins in the product. On the other hand, when comparing the level of inclusion used by the authors (Goes et al., 2015 and Justen et al., 2017) of 9\% with flour made from the same species of fish, despite using another type of waste, it is 
possible to notice that the variation in protein content was $9.8 \%$ to $10.28 \%$, respectively, while in this study, with an addition of $10 \%$, the protein content was $11.04 \%$, slightly higher than the values found by the authors mentioned.

In this experiment, with the inclusion of smoked tilapia trimmings, the protein contents rose according to the increase in the percentage of flour included, presenting a positive linear equation that explains these results $(Y=7,347249-0,304616 \mathrm{X}$, $\mathrm{R}^{2}=94,07$ ); the contents went from $7.06 \%$ (control - without flour) to $11.44 \%$ with the inclusion of $15 \%$ flour, resulting in an increase of $38.29 \%$ protein in the extruded snacks.

The carbohydrate decreased as the levels of inclusion of Nile Tilapia trimmings flour were increased, so the equation that explains the results has a negative linear effect $\left(Y=78,13807-0,370901 X, R^{2}=99,90\right)$. The carbohydrate content in snacks without fish meal was $78.20 \%$, while with $15 \%$ of fish meal added, the content reached $72,63 \%$ (Table 2), with a 7.12\% reduction in carbohydrates with the increased addition of smoked trimmings flour in the extruded snacks.

The moisture content showed a quadratic effect, whose equation was $Y=6,0674-0,1939 X+0,01233 X^{2}\left(R^{2}=96,24 \%\right)$, with a range of 5.26 to $6.03 \%$ (Table 2). Everything indicates that this result must be related to greater or lesser dehydration at the end of the snack tempering process. With the reduction of moisture that, if carried out by using a flame of fire in a stainlesssteel cylinder called coating pan, to make the snacks crispy, occurs before and during the process of tempering the snacks. Goes et al. (2015) reported moisture levels from 6.2 to $7.07 \%$ in snacks, with snacks with tilapia flour having the highest percentage. According to Coradini et al. (2015) products with more than $14 \%$ moisture are likely to have lumps that damage the production of cookies and snacks. Other authors cited in this work say that products with high moisture levels tend to develop microorganisms such as fungi and yeasts, with decreased stability and shelf life (Pires, 2014, Goes et al., 2017, Rodrigues et al., 2015). The lower moisture content is also very important in extruded snacks, as this gives the product greater crispness.

According to Coradini et al. (2015), when comparing products that can be enriched with fish meal, this new product had a higher nutritional value, mainly with increased levels of proteins, minerals and reduced carbohydrates, often improving the caloric value of the product.

The inclusion of tilapia trimmings flour in extruded snacks resulted in a lower Aw in snacks (0.45 to 0.50), with Table 2 showing that the moisture was also significantly lower than in those without flour. Snacks without fish meal showed 0.58 of water activity, which is higher when compared to snacks with fish meal. These results corroborate those reported by Juste et al (2017), who mention that snacks with the inclusion of fish meal ranged from 0.50 to 0.53 at Aw, while without fish meal Aw was 0,57 . According to the authors, the inclusion of fish meal in extruded snacks provides a reduction in Aw, thus ensuring better microbiological stability of the product. Uboldi-Eiroa (1981) states that these foods can be classified as a food with low water activity, because this class contains less than $20 \%$ moisture and an Aw below 0.60 .

The $\mathrm{pH}$ was significantly higher in snacks with the inclusion of different levels of tilapia trimmings flour, however there was no effect of the different levels of inclusion of flour in the snacks. The $\mathrm{pH}$ of snacks without fish meal was 6.22, while snacks with different levels of fish meal ranged from 7.0 to 7.3. These snacks, as they have a higher percentage of meat (protein) in their composition, tended to have a higher $\mathrm{pH}$, since fish meat has a $\mathrm{pH}$ closer to neutrality.

\subsection{Sensory analysis of extruded snacks}

As for sensory analysis, its measurement is highly relevant, as it reveals the degree of sympathy, acceptance or even the intention to purchase a certain product. In this study, it is noted that, regardless of the level of inclusion of the flavored trimmings flour in the extruded snacks, there was no significant difference for the evaluated attributes. The grades ranged from 7.0 to 8.05, corresponding according to the 9-point hedonic scale (Dutcosky, 2011) as I liked it moderately to I liked it very much.

Thus, the scores given by the tasters suggest that the aroma, color, texture, taste and general impression determine good acceptance and consumption of this type of snacks (Table 3). 
Table 3. Sensory analysis of extruded corn snacks with inclusion levels of Nile tilapia trimmings flour.

\begin{tabular}{|c|c|c|c|c|c|c|}
\hline \multirow{2}{*}{$\begin{array}{l}\text { Sensory } \\
\text { analysis }\end{array}$} & \multicolumn{4}{|c|}{ Inclusion levels of trimmings flour (\%) } & \multirow[t]{2}{*}{ P.Value } & \multirow{2}{*}{$\begin{array}{l}\text { C.V. } \\
(\%)\end{array}$} \\
\hline & $\mathbf{0}$ & 5 & 10 & 15 & & \\
\hline Aroma & $7,15 \pm 0,30$ & $7,70 \pm 0,25$ & $7,55 \pm 0,10$ & $7,40 \pm 0,05$ & 0,7321 & 21,47 \\
\hline Color & $7,70 \pm 0,02$ & $8,05 \pm 0,33$ & $7,60 \pm 0,12$ & $7,55 \pm 0,17$ & 0,6290 & 17,12 \\
\hline Texture & $7,65 \pm 0,07$ & $7,80 \pm 0,08$ & $7,90 \pm 0,18$ & $7,55 \pm 0,17$ & 0,8356 & 16,83 \\
\hline Taste & $7,35 \pm 0,10$ & $7,65 \pm 0,20$ & $7,70 \pm 0,05$ & $7,10 \pm 0,35$ & 0,5852 & 19,66 \\
\hline $\begin{array}{l}\text { General } \\
\text { impression }\end{array}$ & $7,00 \pm 0,39$ & $7,50 \pm 0,11$ & $7,65 \pm 0,26$ & $7,40 \pm 0,01$ & 0,5357 & 20,83 \\
\hline $\begin{array}{l}\text { Purchase } \\
\text { intention }\end{array}$ & $3,85 \pm 0,24$ & $4,20 \pm 0,11$ & $4,35 \pm 0,26$ & $3,95 \pm 0,14$ & 0,4398 & 26,21 \\
\hline
\end{tabular}

Means \pm standard deviation. $\mathrm{CV}=$ Coefficient of Variation. Source: Authors.

Goes et al. (2015) reported that snacks with 9\% tilapia flour obtained good scores from 6.89 to 7.68 (6 to 7 , corresponding to slightly liked to moderately liked), for all the tested criteria, but lower than the scores obtained in this study with the use of trimmings flour, whose numbers ranged from 7.0 to 8.05 (Table 3). However, Goes et al. (2015) mentioned that the lowest scores were obtained by snacks with the inclusion of tuna flour (3.98 to 5.47, I disliked moderately to neither liked / nor disliked, that is, indifferent), with the highest score attributed to crispness (texture), which may be associated with the lower moisture content present in these snacks (6.64\%). Snacks with the inclusion of sardine flour also did not score high according to the judges, ranging from 4 (slightly disliked) to 6 (I liked it slightly). The snacks that most resembled the results of the inclusion of the tilapia flour were the ones with salmon (5, neither liked / nor disliked, to 7, which means I liked moderately), but the highest score was attributed only to the color. This higher score was due to the color of the salmon, which ended up influencing the apparent color of the snacks with the inclusion of flour from this fish species.

The tasters' opinions revealed good purchase intention, considering that the ratings given by the tasters were close to 4 , on the 5-point hedonic scale, with extremes 1 (definitely would not buy) and 5 (definitely would buy) (Damasio \& Silva, 1996) (Table 3)

The extruded snacks with the inclusion of smoked tilapia trimmings showed excellent acceptance, and each attribute was evaluated. The aroma presented $82.78 \%$ of acceptance, the color and texture of snacks $85.83 \%$, the flavor $82.78 \%$ and the general impression $82.08 \%$. Consequently, it is a product that presented above $70 \%$ of acceptance, which is considered, according to Dutcosky (2011), as an approved product with excellent acceptance results to be commercialized. Therefore, due to the results of the sensory analysis, the product is suitable for commercial production with good acceptance rates by the tasters. These results also corroborate the statement made by Coradini et al. (2015), who says that products such as cookies and crackers with the inclusion of fish meals and fish products in the preparation have shown good acceptance when the sensory evaluation is carried out.

In this experiment, the inclusion of fish meal also demonstrated good chemical, microbiological and sensory characteristics in the product, indicating snacks with good acceptance by consumers. In addition to these aspects, by consuming the snacks, young people and children can indirectly acquire the habit of eating fish, thus benefiting the tilapia production chain and the use of fillet by-products.

Further studies should be carried out in order to deepen the current results, evaluating the levels of minerals, fatty acids and even the amino acids present, mainly due to the excellent biological quality of the protein, the inclusion of higher percentages 
of this flour in extruded snacks, as well as, evaluate the product with people of different age groups and the shelf life of these extruded snacks.

\section{Conclusions}

The Nile tilapia smoked trimmings flour presented a high protein content and a low content of ash and carbohydrates, with potential for the enrichment of products with low nutritional value. The inclusion of this smoked trimmings flour in extruded corn snacks has caused a significant increase in crude protein content and a reduction in carbohydrate. The smoked trimmings flour and the extruded snacks showed good microbiological quality, being within the requirements for human consumption. It is recommended to include up to $15 \%$ of Nile tilapia trimmings flour in extruded corn snacks with an increase in protein content of up to $38.29 \%$ and a reduction of up to $7.12 \%$ in carbohydrates, presenting excellent results of acceptance and intention to purchase the product if it were on the market. It is suggested to apply this flour in other food products such as pasta, soups, meat products.

\section{References}

Ariño, A., Beltrán, J. A., Herrera, A. \& Roncalés, P. (2013). Fish and seafood: Nutritional Value. IN: Caballero, B. Encyclopedia of Human Nutrition (3a ed.). Waltham, 254-261.

American Public Health Association - APHA. (2001). Compendium of methods for the microbiological examination of foods. APHA.

Arruda, L. F., Borghesi, R., Brum, A., D'arce, M. R. \& Oetterer, M. (2006). Nutritional aspects of Nile tilapia (Oreochromis niloticus) silage. Ciência $e$ Tecnologia de Alimentos, 26(4), 749-756.

Association Of Official Analytical Chemists- AOAC. (2005). Official methods of analyses of the association of analytical chemists. AOAC.

Bligh, E. G \& Dyer, W. J. (1959). A rapid method of total lipid extraction and purification. Canadian Journal of Biochemistry and Physiology, 37(8), 911-17.

Boscolo, W. R. B., Feiden, A. \& Signor, A. A. (2007). Farinha de resíduos da indústria de filetagem de tilápias. In: Boscolo, W.R.; Feiden, A. (Orgs.) Industrialização de tilápias. Toledo: GFM Gráfica e editora, 135-150.

Brasil. (2001). Ministério da Saúde. Agência Nacional de Vigilância Sanitária. Resolução RDC n. 12, de 02 de janeiro de 2001. Regulamento Técnico sobre os padrões microbiológicos para alimentos.

Capriles, V. D., Soares, R. A. M., Pinto e Silva, M. E. M., Arêas, J. A. G. \& Arêas, J. A. G. (2009). Effect of fructans-based fat replacer on chemical composition, starch digestibility and sensory acceptability of corn snacks. International Journal of Food Science \& Technology, 44, $1895-1901$.

Chambó, A.P., Souza, M. L. R. de, Oliveira, E. R. N. de, Mikcha, J. M. G., Marques, D. R., Maistrovicz, F. C., Visentainer, J. V. \& Goes, E. S. dos R. (2018). Roll enriched with Nile tilapia meal: sensory, nutritional, technological and microbiological characteristics. Food Science and Technolgy, 38(4), 726-732.

Coradini, M. F., Franco, M. L. R. S., Verdi, R., Goes, E. S. R., Kimur, K. S. \& Gasparino, E. (2015). Quality evaluation of onion biscuits with aromatized fishmeal from the carcasses of the nile tilápia. Boletim do Instituto da Pesca, 41, 719- 728.

Damásio, M. H. \& Silva, M. A. A. P. (1996). Curso de treinamento em análise sensorial. Apostila Campinas: Fundação Tropical de Tecnologia "André Tosello". Dutcosky, S. D. (2011). Análise sensorial de alimentos. (3a ed.), Champagnat, p. 426.

Ferreira, R. E. (2006). Avaliação de parâmetros do processo de extrusão e do teor de farelo de trigo adicionado em características de "snacks” expandidos de milho. Tese de doutorado. Universidade Estadual de Campinas, Campinas. 162 f. 2006

Franco, M. L. R. S., Abreu, B. B., Sacomanni, A. P. O., Vesco, A. P. D., Vieira, V. I., Mikcha, J. M. G., Gasparino, E. \& Delbem, A.C.B. (2013). Elaboración de cookies y galletas con inclusión de harina de pescado. Infopesca Internacional, 53, 30-33.

Godoy, L. C., Franco, M. L. R. S., Franco, N. P., Silva, A. F., Assis, M. F., Souza, N. E., Matsushita, M., \& Visentainer, J. V. (2010). Análise sensorial de caldos e canjas elaborados com farinha de carcaças de peixe defumadas: aplicação na merenda escolar. Ciência e Tecnologia de Alimentos, $30,86-89$.

Goes, E. S. R., Souza, M. L. R. de, Campelo, D. A. V., Yoshida, G. M., Xavier, T. O., Moura, L. B. \& Monteiro, A. R. G. (2015). Extruded snacks with the addition of different fish meals. Food Science and Technology, 35(4), 683-689.

Goes, E. S. dos R., Souza, M. L. R. de., Michka, J. M. G., Kimura, K. S., Lara, J. A. F. de., Delbem, A. C. B. \& Gasparino, E. (2016). Fresh pasta enrichment with protein concentrates of tilapia: nutritional and sensory characteristics. Food Science and Technology, 36(1), 76-82.

Goes, E. S. R., Feiden, A., Veit, J. C., Finkler, J. K., Goes, M. D. \& Boscolo, W. R. (2017). Elaboração de biscoitos tipo cookies com inclusão de peixe. Revista Agrarian, 10(37), 245-253. 
Research, Society and Development, v. 10, n. 8, e33410817243, 2021

(CC BY 4.0) | ISSN 2525-3409 | DOI: http://dx.doi.org/10.33448/rsd-v10i8.17243

Justen, A. P., Franco, M. L. R. S., Monteiro, A. R. G., Mikcha, J. M. G., Gasparino, E. \& Delben, A. B. (2011). Inclusión de harina de pescado en snacks. Infopesca Internacional, 47, 35-38.

Justen, A. P., Souza, M. L. R., Monteiro, A. R., Mikcha, J. M., Gasparino, E., Delbem, Á. B., Carvalho, M. R. B., Del Vesco, A. P. (2017). Preparation of extruded snacks with flavored flour obtained from the carcasses of Nile tilapia: physicochemical, sensory, and microbiological analysis. Journal of Aquatic Food Product Technology, 26(3), 258-266.

Kimura, K. S., Souza, M. L. R., Gasparino, E., Mikcha, J. M. G., Chambo, A. P. S., Verdi, R., Coradini, M. F., Marques, D. R., Feihrmann, A., Goes, E. S. R. (2017). Preparation of lasagnas with dried mix of tuna and tilapia. (2017). Food Science and Technology, 37(3), 507-514.

Matiucci, M. A., dos Santos, I. C., Oliveira, G. G., Araújo, E. dos S., Corrêa, S. S., Ribeiro, R. P., de Souza, M. L. R. \& Feihrmann, A. C. (2021). Use of tilápia fillet residues in pâté with the addition of oregano essential oil. Research, Society and Development, 10(2), e59510213059.

Pereira, S. A., Shitsuka, D. M., Parreira, F. J. \& Shitsuka, R. (2018). Metodologia da pesquisa científica. UFSM.

Petenuci, M. E., Stevanato, F. B., Morais, D. R., Santos, L. P., Souza, N. E. \& Visentainer, J. V. (2010). Composição e estabilidade lipídica da farinha de espinhaço de tilápia. Ciência e Agrotecnologia, 34(5), 1279-1284.

Pires, D. R., Morais, A. C. N., Costa, J. F., Goes, L. C.D. S. A. \& Oliveira, G. (2014). Aproveitamento do resíduo comestível do pescado: aplicação e viabilidade. Revista Verde, 9(5), 34-46.

SAS Institute (Cary, USA). (2010). SAS/STAT Users guide, version 6. (4a ed.), Cary. 943.

Silva, D. J. \& Queiroz, A. C. (2002). Análise De Alimentos: Métodos Químicos e Biológicos. (3a ed.), Universidade Federal de Viçosa, p. $235,2002$.

Souci, S. W., Fachman, H. \& Kraut, E. (2000). Foods Composition and Nutrition - Tables. Medpharm Scientific Publishers.

Souza, M. L. R., Gasparino, E., Del Vesco, A. P., Justen, A. P., Vieira, V. I. \& Mikcha, J. M. G. (2015). Kaftas prepared with V-shaped filleting chips of the Nile tilapia (Oreochromis niloticus) exposed to smoking techniques Acta Scientiarum. Technology, 37(2), 287-291.

Souza, M. L. R.de, Yoshida, G. M., Campelo, D. A. V., Moura, L. B. de, Xavier, T. O. \& Goes, E. S. dos R. (2017). Formulation of fish waste meal for human nutrition Acta Scientiarum Technology, 39, 525-531.

Uboldi-Eiroa, M. N. (1981). Atividade de água: influência sobre o desenvolvimento de microrganismos e métodos de determinação em alimentos. Boletim do Instituto de Tecnologia de Alimentos 18, 353- 383.

Vidotti, R. M. \& Borini, M. S. M. (2006). Aparas da filetagem da tilápia se transformam em polpa condimentada. Panorama da Aquicultura, 16(96), 38-41. 